\title{
On the determination of basal glucose production rate in patients with Type 2 (non-insulin-dependent) diabetes mellitus using primed-continuous 3- ${ }^{3} \mathrm{H}$-glucose infusion
}

\author{
O. Hother-Nielsen and H. Beck-Nielsen \\ Hvidöre Hospital, Klampenborg, Denmark
}

\begin{abstract}
Summary. Using primed-continuous $3-{ }^{3} \mathrm{H}$-glucose infusion, basal glucose production rate has been reported to be $140 \%$ higher than normal or almost normal in hyperglycaemic patients with Type 2 (non-insulin-dependent) diabetes mellitus. To determine whether these markedly different results could be due to the mode of priming: fixed or adjusted, or the mode of calculation: steady state or non-steady state equations, we studied 11 patients with Type 2 diabetes (fasting plasma glucose $8-20 \mathrm{mmol} / \mathrm{l})$. For $6 \mathrm{~h} \quad 3-{ }^{3} \mathrm{H}$-glucose $(0.40 \mu \mathrm{Ci} / \mathrm{min})$ was infused preceded by a priming dose of $40 \mu \mathrm{Ci}$ (fixed priming), or $40 \mu \mathrm{Ci}$.plasma glucose $(\mathrm{mmol} / \mathrm{l}) \cdot 5^{-1}$ (adjusted priming). In diabetic patients the plasma glucose concentration was not constant but declined $0.52 \pm 0.07 \mathrm{mmol} \cdot \mathrm{1}^{-1} \cdot \mathrm{h}^{-1}$. Furthermore, the rate of fall was correlated to the fasting plasma glucose concentration $(r=0.90, p<0.01)$. Thus, the fasting state was not a steady state condition. Using adjusted priming a constant tracer steady state level was obtained within $60 \mathrm{~min}$. In contrast,
\end{abstract}

using fixed priming tracer steady state was not reached within $6 \mathrm{~h}$. The initial tracer level was far below, and increased in time towards the steady state level observed after adjusted priming. Consequently, using Steele's equations after fixed priming, glucose production rates calculated after 90$120 \mathrm{~min}$ were overestimated in proportion to fasting hyperglycaemia. In conclusion: The fasting state in patients with Type 2 diabetes is not a steady state condition. Adjusted priming seems most appropriate in Type 2 diabetes. By estimating glucose production $2 \mathrm{~h}$ after fixed priming or assuming steady state conditions, most previous studies may have overestimated basal glucose production in Type 2 diabetes in proportion to fasting hyperglycaemia.

Key words: $3-{ }^{-3} \mathrm{H}$-glucose, primed-continuous tracer technique, Type 2 (non-insulin-dependent) diabetes, basal glucose turnover, glucose appearance, glucose disappearance, steady-state conditions, Steele's equations.
Elevated basal glucose production rates have been suggested as being responsible for fasting hyperglycaemia in patients with Type 2 (non-insulin-dependent) diabetes mellitus [1]. This suggestion is based on tracer studies using primed-continuous infusions of $3-{ }^{3} \mathrm{H}$-glucose. In many of these studies basal glucose production in the diabetic patients was found to be increased in proportion to fasting hyperglycaemia. Reviewing the literature, however (Table 1), it appears that although the majority of studies have found diabetic glucose production to be markedly elevated [2-18], some studies have reported normal or almost normal rates [19-24]. Therefore, the obvious question must be, whether the basal fasting state in patients with Type 2 diabetes is a high turnover condition where glucose production rates are almost twice that of normal, or a compensated condition where glucose production rates are almost normal.

In most studies reporting elevated rates $[2-4,7-16,18]$ the ratio between priming dose and constant $3-{ }^{3} \mathrm{H}$-glucose infusion rate was constant (fixed priming), whereas in studies reporting normal or slightly elevated rates [19-24], the ratio of priming dose and constant infusion rate was adjusted to the fasting plasma glucose concentration, i.e. in hyperglycaemic subjects the priming dose was increased in proportion to fasting hyperglycaemia (adjusted priming). In some studies non-steady state equations were used because of the non-steady state behaviour of glucose and tracer concentrations, whereas in other studies steady state conditions were assumed and therefore the steady state equation used.

Therefore, todetermine whether glucose production in Type 2 diabetes is markedly elevated or almost normal, it became important to evaluate whether fixed priming or adjusted priming is most appropriate in hyperglycaemic patients with Type 2 diabetes, and furthermore, whether the basal state in these patients is sufficiently close to steady state conditions to justify the use of steady state calculations, or whether non-steady state equations must be used.

In order to elucidate these methodological questions we studied 11 patients with Type 2 diabetes using fixed and adjusted priming on separate occasions. Plasma glucose and tracer concentrations were measured at $10 \mathrm{~min}$ intervals for $6 \mathrm{~h}$, and glucose turnover rates calculated using both steady state and non-steady state equations.

\section{Subjects and methods}

\section{Subjects}

Eleven Type 2 diabetic patients with fasting plasma glucose concentrations ranging from 8 to $20 \mathrm{mmol} / \mathrm{l}$ were selected from our outpatient clinic. None of the patients had received insulin treatment. As a 
Table 1. Published studies comparing $3{ }^{3} \mathrm{H}$-glucose determined hepatic glucose production (HGP) in patients with Type 2 (non-insulin-dependent) diabetes and in non-diabetic control subjects

\begin{tabular}{|c|c|c|c|c|c|c|c|}
\hline $\begin{array}{l}\text { Plasma } \\
\text { glucose } \\
(\mathrm{mmol} / \mathrm{l})\end{array}$ & $\begin{array}{l}\text { Prime } \\
(\mu \mathrm{Ci})\end{array}$ & $\begin{array}{l}3-{ }^{3} \mathrm{H}-\text { glucose } \\
\text { infusion } \\
(\mu \mathrm{Ci} / \mathrm{min})\end{array}$ & $\begin{array}{l}\text { Ratio of } \\
\text { Prime and } \\
\text { Infusion }\end{array}$ & $\begin{array}{l}\mathrm{EQ} \\
\text { time } \\
(\mathrm{min})\end{array}$ & $\begin{array}{l}\text { Basal HGP } \\
\text { diabetic } \\
\text { in percent } \\
\text { of normal }\end{array}$ & Equation & $\mathrm{Re}$ \\
\hline 15.9 & 50 & 0.25 & 200 & 120 & $239^{a}$ & Steele & 2 \\
\hline 15.6 & 50 & 0.50 & 100 & - & $207^{a}$ & Steele & 3 \\
\hline 15.9 & - & - & - & 120 & $196^{\mathrm{a}}$ & Steele & 4 \\
\hline 14.6 & $25-50$ & $0.4-0.6$ & - & 120 & $191^{\mathrm{a}}$ & Steele & 5 \\
\hline 14.7 & $25-50$ & $0.25-0.35$ & - & $>30$ & $191^{\mathrm{a}}$ & Steele & 6 \\
\hline 14.2 & 25 & 0.25 & 100 & $>30$ & $188^{\mathrm{a}}$ & Steele & 7 \\
\hline 14.6 & 30 & 0.60 & 50 & 120 & $175^{\mathrm{a}}$ & Steele & 8 \\
\hline 14.1 & 25 & 0.25 & 100 & $>30$ & $169^{a}$ & Steele & 7 \\
\hline 11.2 & 20 & 0.20 & 100 & 120 & $169^{\mathrm{a}}$ & Steele & 9 \\
\hline 12.2 & 30 & 0.30 & 100 & 180 & $168^{\mathrm{a}}$ & SS & 10 \\
\hline 10.4 & 14 & 0.14 & 100 & 120 & $164^{\mathrm{a}}$ & Steele & 11 \\
\hline 13.9 & 30 & 0.30 & 100 & $120-180$ & $164^{\mathrm{a}}$ & Steele & 12 \\
\hline 14.6 & 50 & 0.50 & 100 & $60-260$ & $163^{\mathrm{a}}$ & Steele & 13 \\
\hline 12.4 & 35 & 0.35 & 100 & $120-180$ & $160^{\mathrm{a}}$ & SS & 14 \\
\hline 10.1 & 14 & 0.14 & 100 & 120 & $156^{\mathrm{a}}$ & Steele & 15 \\
\hline 10.0 & 22 & 0.22 & 100 & 120 & $153^{\mathrm{a}}$ & Steele & 16 \\
\hline 18.2 & $15-35$ & 0.17 & $100-200$ & 120 & $144^{a}$ & SS & 17 \\
\hline 10.9 & 33 & 0.33 & 100 & 120 & $131^{\mathrm{a}}$ & Steele & 18 \\
\hline 9.0 & adj & 0.25 & adj & $120-180$ & $118^{\mathrm{a}}$ & SS & 19 \\
\hline 8.8 & adj & 0.25 & $\mathrm{adj}$ & $120-180$ & $115^{\mathrm{a}}$ & SS & 20 \\
\hline 8.3 & adj & 0.25 & adj & $120-180$ & $115 \mathrm{~ns}$ & SS & 21 \\
\hline 10.5 & adj & 0.40 & adj & $120-180$ & $110 \mathrm{~ns}$ & SS & 22 \\
\hline 11.0 & adj & 0.25 & adj & $120-180$ & $108 \mathrm{~ns}$ & SS & 23 \\
\hline 11.0 & adj & 0.40 & adj & 120 & $105 \mathrm{~ns}$ & SS & 24 \\
\hline
\end{tabular}

${ }^{a} p<0.05$ diabetic patients vs normal subjects. Adj = adjusted to fasting hyperglycaemia. EQ = Equilibration time (i.e. time from start of infusion to end of basal measurement). $\mathrm{SS}=$ steady state

control group seven non-diabetic subjects matched for age and relative weight were also studied. Clinical characteristics of the diabetic patients and control subjects are given in Table 2. All subjects had constant body weight for at least two months before the studies and no medication was allowed for two days before each study. The diabetic patients were without signs of diabetic neuropathy, retinopathy or nephropathy. All the subjects had normal results on screening blood tests of renal and hepatic function. The purpose and risks of the study were carefully explained to all the subjects before informed consent to participate was obtained. The protocol of the study was reviewed and approved by the regional ethical committee of the county of Copenhagen.

\section{Study protocol}

The diabetic patients were studied on two occasions with a 14-day interval using fixed or adjusted priming in randomized order. The nondiabetic control subjects were studied only once since for them adjusted priming equalled fixed priming. On each occasion subjects were admitted to the department on the day before the study and fasted from 22.00 hours. A part from voiding before the study the subjects remained supine during the study period. At 07.30 hours a catheter was inserted in an antecubital vein for infusion of $3-{ }^{3} \mathrm{H}$-glucose and another catheter inserted retrogradely in a contralateral dorsal hand vein for intermittent collection of blood samples. This hand was placed and maintained in a heated plexiglas box [25] to obtain arterialized venous blood [26]. $3{ }^{3} \mathrm{H}$-glucose (New England Nuclear, Boston, Mass., USA) $300 \mu \mathrm{Ci}$ was dissolved in $320 \mathrm{ml} 0.9 \%$ $\mathrm{NaCl}$ and infused at a constant rate of $0.42 \mathrm{ml} / \mathrm{min}(0.40 \mu \mathrm{Ci} / \mathrm{min})$ from 08.00 to 14.00 hours. Immediately before the start of the constant infusion a priming dose of $42 \mathrm{ml}(40 \mu \mathrm{Ci})$ wasinjected on the day of fixed priming. On the day of adjusted priming the priming dose was increased in proportion to the degree of fasting hyperglycaemia: Priming dose $=40 \mu \mathrm{Ci}$-fasting plasma glucose concentration $(\mathrm{mmol} / \mathrm{h}) \cdot 5^{-1}$. The fasting plasma glucose concentration for calculation of the adjusted priming dose was measured at the bedside using an automated glucose oxidase method (Glucose analyser 2, Beckman
Instruments, Fullerton, Calif., USA). Blood samples were collected in fluoride treated tubes at 10 min intervals for determination of plasma glucose and plasma $3-{ }^{3} \mathrm{H}$-glucose activity, and every $60 \mathrm{~min}$ in heparin-trasylol treated tubes for determination of plasma insulin, $\mathrm{C}$ peptide and glucagon, and in ice-chilled tubes for determination of non-esterified fatty acids (NEFA). Blood samples were immediately centrifuged at $5^{\circ} \mathrm{C}$ and plasma stored at $-20^{\circ} \mathrm{C}$ until assay.

\section{Indirect calorimetry}

Indirect calorimetry was performed using a computerized flowthrough canopy gas analyser system (Deltatrac, Datex, Helsinki, Finland). Briefly, air is suctioned at a rate of 401 per min through a canopy placed over the head of the subject. Samples of inspired and expired air are analysed for oxygen concentration using a paramagnetic differential oxygen sensor and for carbon dioxide using an infrared carbon dioxide sensor. Signals from the gas analysers are processed by the computer and oxygen consumption and carbon dioxide production are calculated and recorded once per min. The average gas exchange rates recorded over $40 \mathrm{~min}$ in the periods $60-120 \mathrm{~min}$ and $300-360 \mathrm{~min}$ were used to calculate rates of glucose oxidation, lipid oxidation and energy expenditure as previously described [27, 28]. In this calculation a urinary nitrogen excretion of $13 \mathrm{~g} / 24 \mathrm{~h}$ was assumed. Before each measurement period the gas analysers were calibrated with precision gas mixtures.

\section{Analytical determinations}

Glucose in plasma and urine was analysed as previously described [29]. For $3-{ }^{3} \mathrm{H}$-glucose activity $500 \mu \mathrm{l}$ of plasma was deproteinized with $1 \mathrm{ml} \mathrm{Ba}(\mathrm{OH})_{2}, 0.3 \mathrm{~N}$ and $1 \mathrm{ml} \mathrm{ZnSO}_{4}, 0.3 \mathrm{~N}$ (Sigma, St.Louis, Mo., USA), $1000 \mu \mathrm{l}$ of the supernatant was placed in $20 \mathrm{ml}$ glass scintillation vials, evaporated to dryness under compressed air to eliminate ${ }^{3} \mathrm{H}$ labelled water, resuspended in $1000 \mu \mathrm{l}$ distilled water and mixed with $10 \mathrm{ml}$ Aqualuma Plus (Lumac, Schaesberg, The Netherlands). After 3 days at room temperature to allow for disappearance 

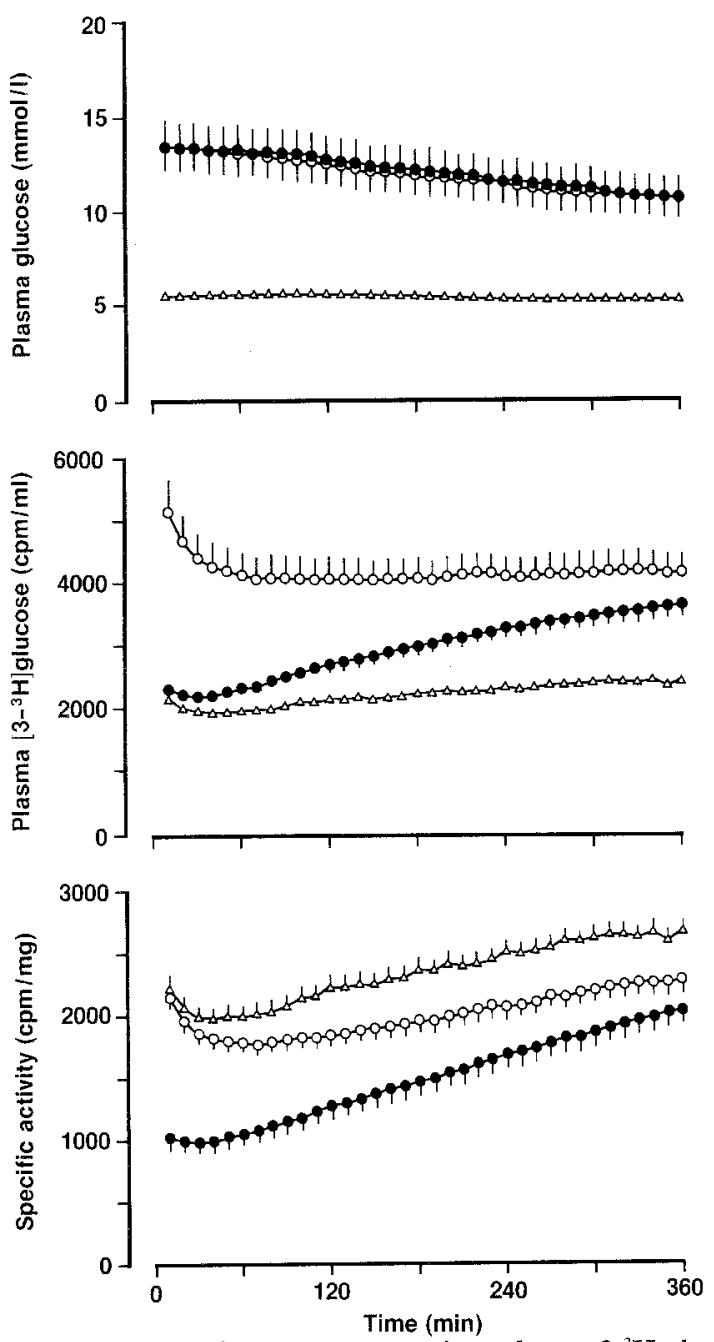

Fig.1. Plasma glucose concentration, plasma $3-{ }^{3} \mathrm{H}$-glucose activity and glucose specific activity in control subjects $\left(-\triangle_{-}\right)$and in Type 2 (non-insulin-dependent) diabetic patients during continuous infusion of $3-{ }^{3} \mathrm{H}$-glucose $(0.40 \mu \mathrm{Ci} / \mathrm{min})$ preceded by a fixed priming dose $(40 \mu \mathrm{Ci})(-\mathbf{-})$ or an adjusted priming dose $(40 \mu \mathrm{Ci}$. plasma glucose $\left.(\mathrm{mmol} / \mathrm{l}) \cdot 5^{-1}\right)\left(-\mathrm{O}_{-}\right)$

of chemoluminiscense, the vials were counted $(20 \mathrm{~min})$ in a liquid scintillation counter (Tri-Carb 1500, Packard Instruments, Downers Grove, Ill., USA). For the determination of infusate and background activity $500 \mu \mathrm{l}$ of the subjects' baseline plasma with and without addition of $10 \mu \mathrm{l}$ of the infusate solution was run through the same procedure. Both plasma, infusate and background determinations were performed in duplicate and in the same assay for a given subject. In all plasma determinations ${ }^{3} \mathrm{H}$-glucose activity was more than 20 -fold above the background level. Plasma insulin [30], C-peptide [31] and glucagon [32] concentrations were measured by RIA. Plasma NEFA concentration was determined with a commercial kit using an automated analyser (Cobas Mira, Roche, Basle, Switzerland).

\section{Calculations}

Glucose turnover rates were calculated at 10 min intervals using both the steady state equation [21, 33-35] and Steele's non-steady state equations [36-39] as in the previous studies.

Steady state equation:

$\mathrm{Ra}=\mathrm{Rd}=\frac{\mathrm{Ra} *}{\mathrm{SA}}$

Since only one glucose turnover rate is calculated from Eq.1, we have in this paper used the term glucose turnover rate (GT) to identify rates calculated using Eq. 1 .
Steele's equations for non-steady state:

$$
\begin{aligned}
& \mathrm{Ra}=\frac{\mathrm{Ra} *-\mathrm{p} \cdot \mathrm{V}_{\mathrm{D}} \cdot \mathrm{C} \cdot(\mathrm{dSA} / \mathrm{dt})}{\mathrm{SA}} \\
& \mathrm{Rd}=\mathrm{Ra}-\mathrm{p} \cdot \mathrm{V}_{\mathrm{D}} \cdot \frac{\mathrm{dC}}{\mathrm{dt}}
\end{aligned}
$$

where $\mathrm{Ra}$ and $\mathrm{Rd}$ are the rates of appearance and disappearance of unlabelled glucose, $\mathrm{Ra}^{*}$ is tracer infusion rate $(\mathrm{cpm} / \mathrm{min}), \mathrm{SA}$ is glucose specific activity ( $\mathrm{cpm} / \mathrm{mg}), \mathrm{C}$ is plasma glucose concentration $(\mathrm{mg} / \mathrm{ml})$, and $V_{D}$ is the distribution volume of glucose taken as $200 \mathrm{ml} / \mathrm{kg}$ body weight, and $\mathrm{p}$ is the pool fraction taken as 0.65 [40]. During each $10 \mathrm{~min}$ interval $\left(t_{1}\right.$ to $\left.t_{2}\right)$ we used the approximations $\mathrm{C}=\left(\mathrm{C}_{1}+\mathrm{C}_{2}\right) / 2, \mathrm{SA}=\left(\mathrm{SA}_{1}+\mathrm{SA}_{2}\right) / 2, \mathrm{dC}=\left(\mathrm{C}_{2}-\mathrm{C}_{1}\right)$ and $\mathrm{dSA}=$ $\left(\mathrm{SA}_{2}-\mathrm{SA}_{1}\right)$. In order to minimize the influence of random error the individual curves of plasma glucose and plasma $3-{ }^{3} \mathrm{H}$-glucose activity were smoothed as proposed by Wolfe [39] using the optimal segments method [41] before turnover rates were calculated.

\section{Statistical analysis}

All data are presented as mean \pm SEM. Statistical comparisons between and within groups were performed using the non-parametric Mann-Whitney and Wilcoxon tests for unpaired and paired data. In correlation analysis Spearmans rho was used. $p$ values less than 0.05 were considered significant.

\section{Results}

\section{Plasma insulin, C-peptide, NEFA, and glucagon concentrations}

In diabetic patients fasting plasma insulin and C-peptide concentrations were slightly higher than normal $(15 \pm 2$ vs $9 \pm 1 \mathrm{mU} / \mathrm{l}, p<0.05$, and $0.72 \pm 0.07$ vs $0.54 \pm 0.07 \mathrm{nmol} / \mathrm{l}$, $p=\mathrm{NS})$, whereas fasting plasma NEFA $(0.67 \pm 0.07$ vs $0.68 \pm 0.06 \mathrm{mmol} / \mathrm{l})$ and glucagon concentrations (35 \pm 4 vs $30 \pm 5 \mathrm{ng} / \mathrm{ml}$ ) were normal. Both plasma insulin, C-peptide, NEFA and glucagon levels remained unchanged during the following $6 \mathrm{~h}$ study period, where the subjects continued fasting.

Time course for plasma glucose, $3-{ }^{3} \mathrm{H}$-glucose activity and glucose specific activity

The diabetic patients plasma glucose concentration was not constant, but decreased on average $0.52 \pm 0.07 \mathrm{mmol} \cdot \mathrm{l}^{-1} \cdot \mathrm{h}^{-1}$ (Fig. 1), and the rate of fall in plasma glucose over the $6 \mathrm{~h}$ study period was correlated to the fasting plasma glucose concentration at 08.00 hours $(r=0.90, p<0.01)$ (Fig. 2, left panel). In control subjects the plasma glucose concentration remained unchanged. Using adjusted priming in the diabetic patients a steady

Table 2. Clinical characteristics of Type 2 (non-insulin-dependent) diabetic patients and control subjects

\begin{tabular}{lll}
\hline & $\begin{array}{l}\text { Diabetic } \\
\text { patients }\end{array}$ & $\begin{array}{l}\text { Control } \\
\text { subjects }\end{array}$ \\
\hline Male/female & $6 / 5$ & $3 / 4$ \\
Age (years) & $56 \pm 4$ & $55 \pm 3$ \\
Body mass index $\left(\mathrm{kg} / \mathrm{m}^{2}\right)$ & $28 \pm 1$ & $27 \pm 2$ \\
Plasma glucose $(\mathrm{mmol} / \mathrm{l})$ & $12.8 \pm 1.2$ & $5.1 \pm 0.1^{\text {a }}$ \\
Plasma insulin $(\mathrm{mU} / 1)$ & $15 \pm 2$ & $9 \pm 1^{\mathrm{a}}$ \\
Plasma C-peptide $(\mathrm{nmol} / \mathrm{l})$ & $0.72 \pm 0.07$ & $0.54 \pm 0.07$ \\
Diabetes duration (years) & $8 \pm 2$ & \\
\hline
\end{tabular}

mean \pm SEM, ${ }^{a} p<0.05$ 
606

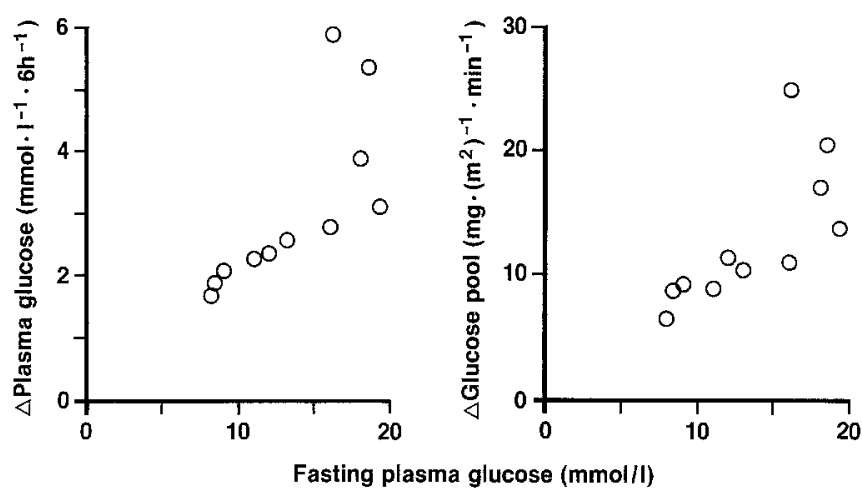

Fig.2. Correlation between fasting plasma glucose concentration and (left panel) the spontaneous fall in plasma glucose concentration over the 6 h study period $(r=0.92, p<0.01)$, and (right panel) the rate of change in glucose pool calculated as $\mathrm{V}_{\mathrm{D}} \cdot(\mathrm{dC} / \mathrm{dt})(r=0.88$, $p<0.01) . \mathrm{C}=$ glucose concentration, $\mathrm{V}_{\mathrm{D}}=$ distribution volume $(200 \mathrm{ml} / \mathrm{kg})$

state level of $3-{ }^{3} \mathrm{H}$-glucose activity was obtained within $60 \mathrm{~min}$ (Fig.1), and this level remained constant during the rest of the study $(4114 \pm 342 \mathrm{cpm} / \mathrm{ml}$ after $60 \mathrm{~min}$ and $4188 \pm 311 \mathrm{cpm} / \mathrm{ml}$ after $360 \mathrm{~min}$ ). In contrast using fixed priming in the diabetic patients plasma activity was much lower at $60 \mathrm{~min}(2323 \pm 88 \mathrm{cpm} / \mathrm{ml})$ and although it increased asymptotically towards the steady state level obtained after adjusted priming, it was still $12.6 \%$ below after $360 \mathrm{~min} \quad(3659 \pm 224$ vs $4188 \pm 311 \mathrm{cpm} / \mathrm{min}$, $p<0.05)$. The change in average plasma activity during the last $30 \mathrm{~min}$ of the $2 \mathrm{nd}, 3 \mathrm{rd}, 4 \mathrm{th}, 5$ th and 6 th hour after fixed priming was $8.2,5.4,5.6,2.8$ and $2.2 \%$. In control subjects the plasma activity plateaued between 30 and $120 \mathrm{~min}$, but thereafter increased slightly during the following $4 \mathrm{~h}$ from $2131 \pm 35$ to $2437 \pm 62 \mathrm{cpm} / \mathrm{ml}$. Specific activity $10 \mathrm{~min}$ after adjusted priming was identical in diabetic patients and control subjects, whereas using fixed priming specific activity in diabetic patients was severely reduced $(1034 \pm 103$ vs $2164 \pm 94 \mathrm{cpm} / \mathrm{mg}, p<0.01)$. During the study specific activity increased reflecting the changes in plasma $3-{ }^{3} \mathrm{H}-$ glucose activity and plasma glucose concentration, simply because specific activity ( $\mathrm{cpm} / \mathrm{mg}$ ) is plasma activity $(\mathrm{cpm} / \mathrm{ml})$ divided by plasma glucose concentration $(\mathrm{mg} / \mathrm{ml})$.

\section{Turnover rates in diabetic patients. Fixed $v$ s adjusted priming}

Using the steady state equation calculated glucose turnover rates (GT) were on average $62 \%$ higher after fixed than after adjusted priming in the 90-120 min interval, whereas, at 330-360 min this difference was reduced to $18 \%$ (Fig. 3, Table 3). Also using Steele's non-steady state equations in the 90-120 min interval calculated turnover rates were on average higher after fixed than after adjusted priming (Ra: $34 \%, p<0.01$, Rd: $29 \%, p<0.01$ ), whereas, after prolonged tracer equilibration at 330-360 min these differences became insignificant (Ra: $2 \%, p=\mathrm{NS}, \mathrm{Rd}: 4 \%$, $p=$ NS) (Fig. 3, Table 3). Also correlations between glucose turnover rates and plasma glucose concentrations were different depending on whether fixed or adjusted priming was used (Fig.4). After fixed priming both glucose turnover rate (GT) and Ra calculated using Steele's equation were highly correlated to plasma glucose concentra- tion at $90-120 \mathrm{~min}(r=0.97, p<0.001$, and $r=0.86$, $p<0.01$ ) (Fig. 4). However, as tracer steady state was approached, during prolonged infusion, these correlations decreased. At 330-360 min the correlation was still significant for glucose turnover (GT) $(r=0.86, p<0.01)$ but not for $\operatorname{Ra}(r=0.37, p=\mathrm{NS})$. Using adjusted priming neither glucose turnover rate (GT) nor Ra were correlated to plasma glucose concentrations (Fig. 4).

\section{Turnover rates in diabetic patients and control subjects using adjusted priming}

Using the steady state equation glucose turnover rate (GT) was significantly elevated in diabetic patients throughout the study, (90-120 min: $92 \pm 3$ vs $79 \pm 2$, $p<0.01,150-180 \mathrm{~min}: 87 \pm 3$ vs $75 \pm 3, p<0.01$, and $330-$ $360 \mathrm{~min}: 74 \pm 3$ vs $\left.64 \pm 3 \mathrm{mg} \cdot\left(\mathrm{m}^{2}\right)^{-1} \cdot \mathrm{min}^{-1}, p<0.05\right)$ (Fig. 3, Table 3). Almost identical values were calculated for $\mathrm{Rd}$ using Steele's equations (90-120 min: $93 \pm 3$ vs $72 \pm 2, p<0.01,150-180 \mathrm{~min}: 85 \pm 3$ vs $70 \pm 3, p<0.01$, and $330-360 \mathrm{~min}: 73 \pm 3$ vs $65 \pm 3 \mathrm{mg} \cdot\left(\mathrm{m}^{2}\right)^{-1} \cdot \mathrm{min}^{-1}$, $p<0.05$ ). In contrast, glucose production, $\mathrm{Ra}$ calculated using Steele's equations was only significantly elevated at $90-120 \mathrm{~min}\left(83 \pm 3\right.$ vs $\left.71 \pm 3 \mathrm{mg} \cdot\left(\mathrm{m}^{2}\right)^{-1} \cdot \mathrm{min}^{-1}, p<0.05\right)$ but not at $150-180 \mathrm{~min}\left(76 \pm 3\right.$ vs $68 \pm 3 \mathrm{mg} \cdot\left(\mathrm{m}^{2}\right)^{-1}$. $\left.\min ^{-1}, p=\mathrm{NS}\right)$ or $330-360 \mathrm{~min}(67 \pm 3$ vs $64 \pm 4 \mathrm{mg}$. $\left.\left(\mathrm{m}^{2}\right)^{-1} \cdot \min ^{-1}, p=\mathrm{NS}\right)$. Furthermore, it is seen that using non-steady state equations $\mathrm{Ra}$ in diabetic patients was smaller than $\mathrm{Rd}$ at all time points $(p<0.01)$, simply because plasma glucose concentrations were decreasing. As the rate of fall in plasma glucose concentration correlate to fasting plasma glucose concentration (Fig. 2, left panel), also the difference between $\mathrm{Rd}$ and $\mathrm{Ra}$ calculated as the rate of change in the glucose pool was correlated to fasting plasma glucose concentration $(r=0.88, p<0.01$ ) (Fig. 2, right panel). Calculated using the whole pool this difference averaged $12.4 \pm 1.9 \mathrm{mg} \cdot\left(\mathrm{m}^{2}\right)^{-1} \cdot \mathrm{min}^{-1}$, whereas if only a fraction (0.65) of the pool is used, as in Steele's equations, this difference averaged $8.1 \pm 1.2 \mathrm{mg} \cdot\left(\mathrm{m}^{2}\right)^{-1}$. $\min ^{-1}$.

Table 3. Glucose turnover rates $\left(\mathrm{mg} \cdot\left(\mathrm{m}^{2}\right)^{-1} \cdot \mathrm{min}^{-1}\right)$ calculated after 2,3 , and $6 \mathrm{~h}$ tracer infusion using steady state and non-steady state equations in control subjects and in Type 2 (non-insulin-dependent) diabetic patients using fixed (Fix) or adjusted (Adj) priming

\begin{tabular}{lccc}
\hline \multicolumn{5}{c}{$90-120 \mathrm{~min}$} & $150-180 \mathrm{~min}$ & $330-360 \mathrm{~min}$ \\
\hline Steady state equations: & & & \\
Glucose turnover $(G T)$ & & & \\
Diabetic patients Fix & $149.3 \pm 10.9^{\mathrm{a}}$ & $126.4 \pm 8.7^{\mathrm{a}}$ & $87.3 \pm 4.5^{\mathrm{b}}$ \\
Diabetic patients Adj & $92.0 \pm 3.1$ & $87.0 \pm 3.0$ & $74.0 \pm 2.9$ \\
Control subjects & $78.7 \pm 2.4^{\mathrm{c}}$ & $74.6 \pm 2.7^{\mathrm{c}}$ & $64.1 \pm 3.0^{\mathrm{d}}$ \\
Steele's non-steady state equations: & & \\
Glucose appearance (Ra) & & & \\
Diabetic patients Fix & $111.2 \pm 7.1^{\mathrm{a}}$ & $96.0 \pm 4.9^{\mathrm{a}}$ & $68.4 \pm 2.7$ \\
Diabetic patients Adj & $83.0 \pm 3.1$ & $75.7 \pm 3.2$ & $67.0 \pm 2.7$ \\
Control subjects & $71.2 \pm 2.7^{\mathrm{d}}$ & $68.3 \pm 3.4$ & $64.3 \pm 3.7$ \\
Glucose disappearance (Rd) & & & \\
Diabetic patients Fix & $120.1 \pm 7.7^{\mathrm{a}}$ & $104.2 \pm 5.9^{\mathrm{a}}$ & $76.3 \pm 2.8$ \\
Diabetic patients Adj & $92.8 \pm 3.3$ & $85.4 \pm 3.4$ & $73.2 \pm 2.5$ \\
Control subjects & $72.4 \pm 2.4^{\mathrm{c}}$ & $69.9 \pm 2.9^{\mathrm{c}}$ & $65.2 \pm 3.2^{\mathrm{d}}$ \\
\hline
\end{tabular}

${ }^{\mathrm{a}} p<0.01$ and $^{\mathrm{b}} p<0.05$ fixed vs adjusted priming in diabetic patients, ${ }^{c} p<0.01$ and ${ }^{\mathrm{d}} p<0.05$ control subjects vs diabetic patients using adjusted priming 

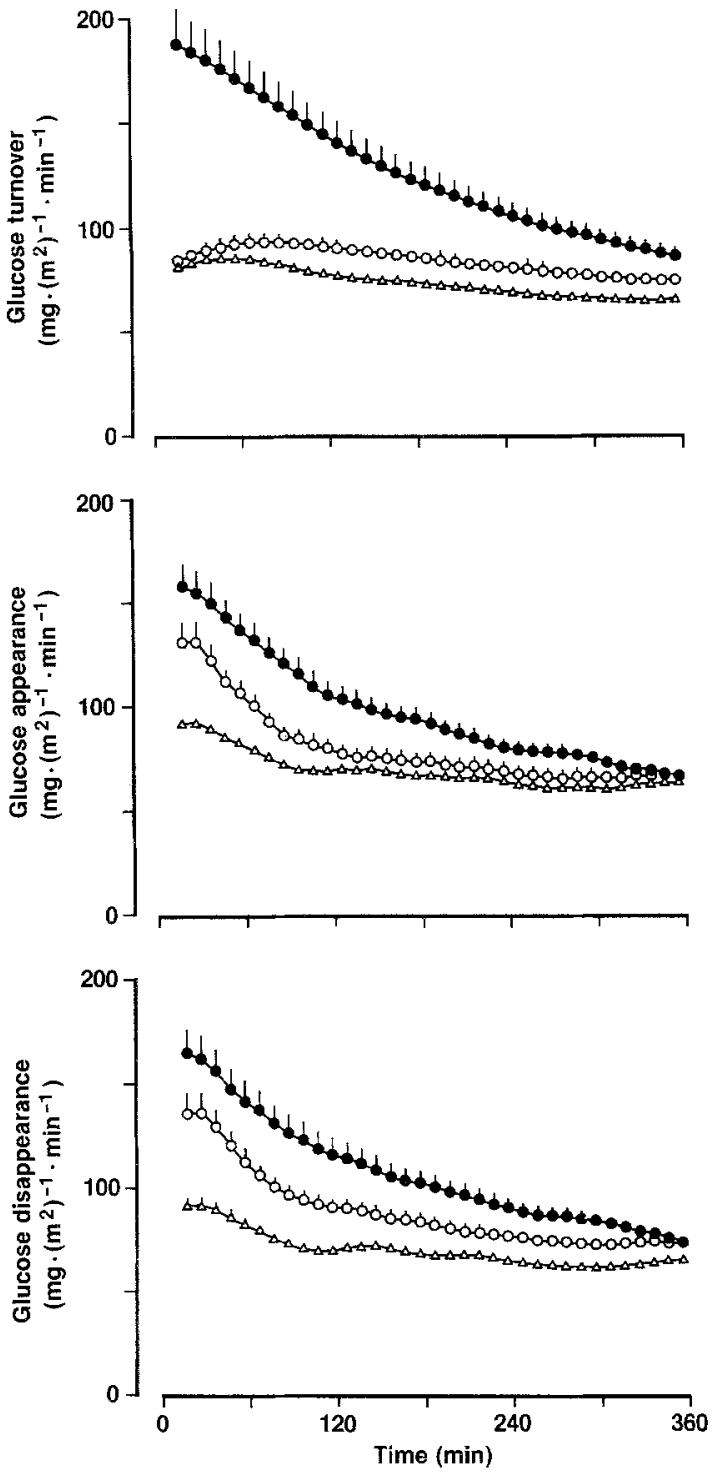

Fig. 3. Glucose turnover rates (GT) calculated using the steady state equation (upper panel), and glucose appearance and disappearance rates calculated using Steele's equations (middle and lower panel) in control subjects $\left(-\Delta^{-}\right)$and in Type 2 (non-insulin-dependent) diabetic patients during fixed $(\bullet$ ) or adjusted $(O)$ primed-continuous infusion of $3-{ }^{3} \mathrm{H}$-glucose

Over time, from 10.00 hours ( $120 \mathrm{~min}$ ) to 14.00 hours (360 min) both tracer determined Ra and Rd decreased in diabetic patients and control subjects (Table $3, p<0.05$ ). Over the same period glucose oxidation rates determined by indirect calorimetry were also reduced in both diabetic patients and control subjects ( $46 \pm 4$ to $35 \pm 4$, and $48 \pm 4$ to $33 \pm 3 \mathrm{mg} \cdot\left(\mathrm{m}^{2}\right)^{-1} \cdot \mathrm{min}^{-1}$, both $\left.p<0.02\right)$, and lipid oxidation increased $(29 \pm 2$ to $35 \pm 2$, and $24 \pm 3$ to $33 \pm 2 \mathrm{mg} \cdot\left(\mathrm{m}^{2}\right)^{-1} \cdot \mathrm{min}^{-1}$, both $\left.p<0.02\right)$, whereas energy expenditure was unchanged $(0.61 \pm 0.02$ to $0.62 \pm 0.02$, and $0.58 \pm 0.02$ to $\left.0.60 \pm 0.02 \mathrm{kcal} \cdot\left(\mathrm{m}^{2}\right)^{-1} \cdot \mathrm{min}^{-1}\right)$.

\section{Discussion}

In previous studies using primed-continuous $3-{ }^{3} \mathrm{H}$-glucose infusion to evaluate basal glucose production in patients with Type 2 diabetes the ratio of priming tracer dose and constant tracer infusion rate was either the same in all sub- jects (fixed priming) or adjusted for the prevalent fasting plasma glucose concentration (adjusted priming). In studies using fixed priming basal glucose production rates in diabetic patients were markedly elevated (31-139\%) [218 , whereas in studies using adjusted priming glucose production rates were normal or only slightly elevated (5-18\%) [19-24]. In the present study we compared fixed and adjusted priming in 11 Type 2 diabetic subjects. Using fixed priming we found markedly higher glucose turnover rates than when using adjusted priming. Although this difference was most pronounced when the steady state equation was used, the difference was also considerable when Steele's non-steady state equations were used. Furthermore, using fixed priming glucose production rates were strongly correlated to plasma glucose concentrations, whereas using adjusted priming no correlation was found. Thus, markedly different conclusions may be reached depending on the mode of priming. Since tracer steady state was obtained 60 min after adjusted priming, but not within $6 \mathrm{~h}$ after fixed priming, it appears likely that turnover rates calculated using adjusted priming may be most correct, whereas turnover rates calculated after fixed priming may be in error. Furthermore, although tracer steady state could be obtained using adjusted priming, glucose concentrations in our diabetic patients were not constant but decreasing at an average rate of $0.52 \mathrm{mmol} \cdot \mathrm{l}^{-1} \cdot \mathrm{h}^{-1}$. Similar changes have been reported in other studies: 0.48 [42], 0.50 [43], 0.5 [44], 0.73 [45] and $0.52 \mathrm{mmol} \cdot \mathrm{l}^{-1} \cdot \mathrm{h}^{-1}$ [13]. Thus, the glucose system in the fasting state is not in steady state in patients with Type 2 diabetes. A decreasing glucose concentration indicates that Ra must be smaller than Rd. In previous studies using adjusted priming [19-24] the steady state equation was used and it was assumed that $\mathrm{Ra}$ was calculated. However, in our study, using adjusted priming glucose turnover rates (GT) calculated using the steady state equation were almost identical to $\mathrm{Rd}$ and higher than $\mathrm{Ra}$ calculated using Steele's non-steady state equations, suggesting that Rd rather than Ra may be calculated when the steady state equation is used in this situation.

Thus, our study suggests that previous studies may have overestimated basal glucose production in hyperglycaemic patients with Type 2 diabetes. Although the overestimation has been most marked in studies using fixed priming, studies using adjusted priming and steady state equations may also have overestimated glucose production to some extent. With this background it seems relevant to reconsider the basic principles of the constant infusion technique and the adequate priming dose and to try to clarify the principles of the steady state and non-steady state equations.

In principle the primed-continuous tracer infusion technique is the constant tracer infusion technique in which a priming dose of tracer is injected at the start of the infusion. With the constant infusion technique the tracer is infused at a constant rate until the tracer has ascended to a constant steady state level. Achievement of tracer steady state is important because at this constant tracer level the tracer disappearance rate $\left(\mathrm{Rd}^{*}\right)$ must equal the known tracer infusion rate $\left(\mathrm{Ra}^{*}\right)$.

The purpose of the priming dose is to instantaneously label the whole glucose pool to the tracer steady state level that would eventually be reached with the constant infusion alone. For a single compartment system the optimal 

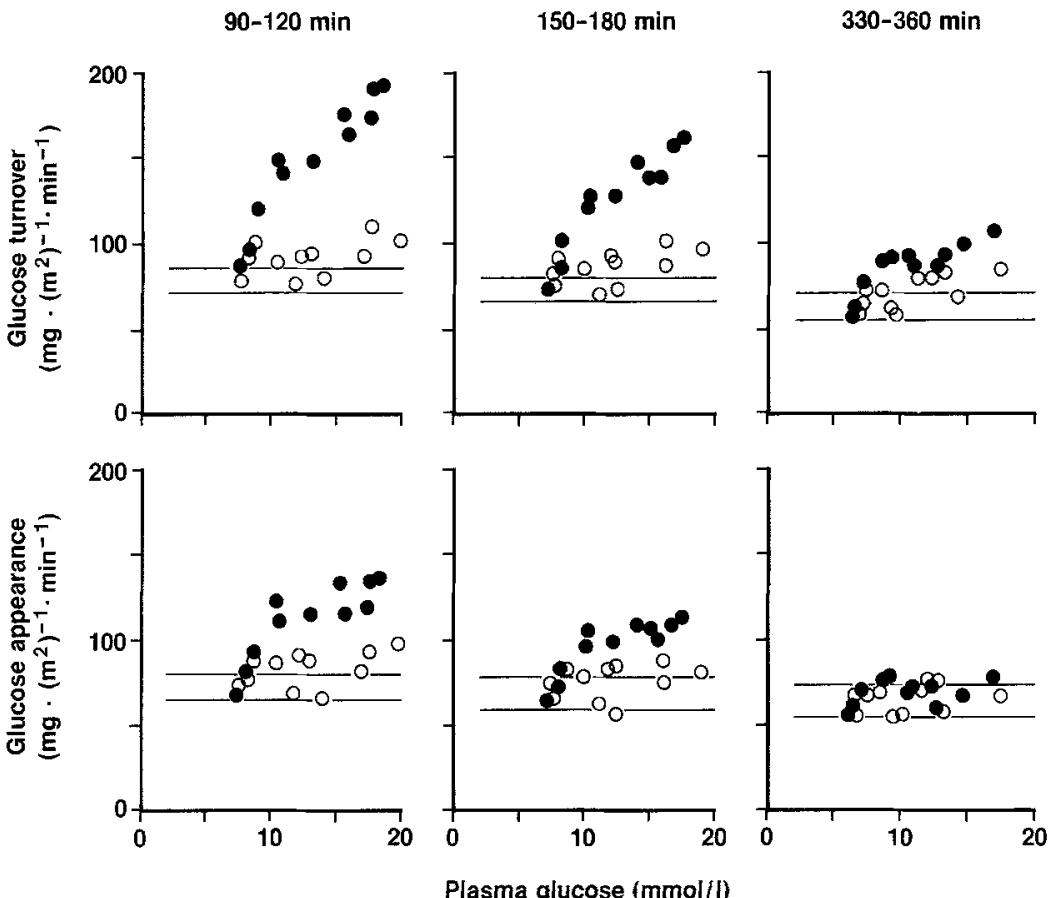

Fig. 4. Correlation between plasma glucose concentration and glucose turnover rate (GT) (upper panel) or glucose appearance rate calculated using Steele's equation (lower panel) after 90-120, 150-180 and 330-360 min tracer infusion in 11 Type 2 (non-insulin-dependent) diabetic patients using fixed ( $)$ or adjusted ( $O$ ) primed-continuous 3- ${ }^{3} \mathrm{H}$-glucose infusion. Mean \pm SD of seven non-diabetic control subjects are indicated by horizontal lines. Using fixed priming the correlation of both glucose turnover (GT) and glucose appearance rate $(\mathrm{Ra})$ to plasma glucose concentration decreased in time (GT: $r=0.97,0.97$, 0.86 , all $p<0.01$, Ra: $r=0.91,0.88$, both $p<0.01$, and $r=0.37, p=\mathrm{NS})$. Using adjusted priming no correlation was found (GT: $r=0.49,0.51,0.46$, Ra: $r=0.47,0.31,0.14$, all $p=$ NS) ratio of priming dose and constant infusion rate depends on the mass of glucose in the pool $\left(\mathrm{V}_{\mathrm{D}} \cdot \mathrm{C}\right)$ and the rate of glucose turnover $(\mathrm{Rd})$ [39]:

$\frac{\text { Priming dose }}{\text { Constant inf. }}=\frac{V_{D} \cdot C}{R d}$

In normal subjects a ratio of $80-100$ has been suggested as being appropriate [33]. Using the figures: $V_{D}=200 \mathrm{ml} / \mathrm{kg}$, $\mathrm{C}=0.9 \mathrm{mg} / \mathrm{ml}, \mathrm{Rd}=2.0 \mathrm{mg} \cdot \mathrm{kg}^{-1} \cdot \mathrm{min}^{-1}$ a ratio of 90 is calculated. In most previous studies a ratio of 100 was used in normal subjects. In diabetic patients the glucose concentration is elevated and $\mathrm{Rd}$ is the unknown to be calculated. From Eq. 4 it is seen that if Rd is expected to be elevated in proportion to glucose concentration (C) so that $\mathrm{C} / \mathrm{Rd}$ remains constant, the same ratio could be used for all subjects (fixed priming). However, if $\mathrm{Rd}$ is expected to be similar in hyperglycaemic patients and in normoglycaemic subjects, then the priming ratio must be increased in hyperglycaemic patients in proportion to the degree of hyperglycaemia (adjusted priming). Our study demonstrates that adjusted priming is more appropriate than fixed priming in patients with Type 2 diabetes because tracer steady state was obtained within 60 min using adjusted priming, whereas tracer steady state was not obtained within $6 \mathrm{~h}$ using fixed priming. This finding also suggests that glucose turnover rates in our Type 2 diabetic patients were not markedly elevated, but near normal.

Concerning the calculation of glucose turnover rates, Radziuk [46] recently suggested that "when glucose tracers are used to study glucose fluxes, the metabolic clearance rate (MCR) is the fundamental measurement from which $\mathrm{Ra}$ and $\mathrm{Rd}$ are themselves derived". This suggestion was based on the essential characteristics of a glucose tracer: that its kinetic and chemical behaviour is exactly analogous to that of glucose. Thus, since the glucose tracer is metabolically indistinguishable from glucose it follows that at any time point the MCR of glucose must equal the MCR of tracer:
$\mathrm{MCR}=\frac{\mathrm{Rd} *}{\mathrm{C} *}=\frac{\mathrm{Rd}}{\mathrm{C}}$

From this fundamental tracer property an equation for Rd can be derived:

$\mathrm{Rd}=\frac{\mathrm{Rd}^{*}}{\mathrm{C}^{*}} \cdot \mathrm{C}$

At tracer steady state $\mathrm{Rd}^{*}$ equals the known tracer infusion rate $\left(\mathrm{Ra}^{*}\right)$. Therefore, at tracer steady state $\mathrm{Rd}$ can be calculated as:

$\mathrm{Rd}=\frac{\mathrm{Ra} *}{\mathrm{C} *} \cdot \mathrm{C}$

When glucose concentration is constant, Ra must equal $\mathrm{Rd}$. However, when glucose concentration is not constant, but either increasing or decreasing, $\mathrm{Ra}$ is not calculated from Eq. 7. In this situation non-steady state calculations become necessary. Basically, the non-steady state equations are derived from the mass balance equations of tracer and glucose $[33,36]$

$\mathrm{V}_{\mathrm{D}} \cdot \frac{\mathrm{dC} *}{\mathrm{dt}}=\mathrm{Ra}^{*}-\mathrm{Rd} *$

$\mathrm{V}_{\mathrm{D}} \cdot \frac{\mathrm{dC}}{\mathrm{dt}}=\mathrm{Ra}-\mathrm{Rd}$

Combining Eq. 6 and Eq. 8, and rearranging Eq. 9 gives:

$\mathrm{Rd}=\frac{\left[\mathrm{Ra} *-\mathrm{V}_{\mathrm{D}} \cdot(\mathrm{dC} * / \mathrm{dt})\right] \cdot \mathrm{C}}{\mathrm{C} *}$
$\mathrm{Ra}=\mathrm{Rd}+\mathrm{V}_{\mathrm{D}} \cdot \frac{\mathrm{dC}}{\mathrm{dt}}$

Adding the pool fraction concept advanced by Steele [36, 40] ( $\mathrm{p}=$ effective pool fraction) we have the equations: 
$\mathrm{Rd}=\frac{\left[\mathrm{Ra} *-\mathrm{p} \cdot \mathrm{V}_{\mathrm{D}} \cdot(\mathrm{dC} * / \mathrm{dt})\right] \cdot \mathrm{C}}{\mathrm{C} *}$

$R a=R d+p \cdot V_{D} \cdot \frac{d C}{d t}$

Mathematically, these equations are identical to Steele's equations (Eq. 2 and Eq.3) and in practice identical rates of glucose appearance or disappearance are calculated whether these equations or Steele's equations are used. The advantage of Eq. 12 and Eq. 13 is that the measured variables, glucose concentration (C) and tracer activity $\left(C^{*}\right)$, are entered directly in the equations, whereas in Steele's version (Eq. 2 and 3 ) the combined variable, specific activity ( $\mathrm{SA}=\mathrm{C}^{*} / \mathrm{C}$ ), was used. Therefore, using Eq. 12 and 13 it is easier to see how changes in tracer and glucose concentration influence the calculated rates of $\mathrm{Ra}$ and $\mathrm{Rd}$. Furthermore, these equations underline the principle that with the tracer technique $R d$ is calculated from the MCR of tracer, whereas Ra is derived indirectly from $\mathrm{Rd}$ using the mass balance of glucose.

Using adjusted priming tracer steady state was obtained after $60 \mathrm{~min}$, whereas using fixed priming a tracer steady state was not obtained. This is important, because at tracer steady state the derivative element $\mathrm{dC} * / \mathrm{dt}$ equals zero, Eq. 12 is reduced to Eq. 7, and Rd can be accurately calculated independently of model assumptions. In contrast, at tracer non-steady state non-steady state equations must be used and thereby the calculated $\mathrm{Rd}$ values become dependent on model assumptions, i.e. instantaneous mixing throughout the whole pool and the concept of an effective pool fraction. Therefore, Rd values after adjusted priming were most correct, whereas the higher $\mathrm{Rd}$ values after fixed priming must represent artefactual overestimations. From Eq. 13 it is clear that when Rd is overestimated using fixed priming, Ra will also be overestimated. Figure 4 (lower panel) shows that the overestimated $\mathrm{Ra}$ after fixed priming was correlated to plasma glucose concentrations. However, as tracer steady state was approached during prolonged tracer infusion this correlation decreased and became insignificant after 360 min.

In some previous studies [19-24] adjusted priming was used and it was assumed that $\mathrm{Ra}$ was calculated from the steady state equation. Equation 7 shows that in principle $\mathrm{Rd}$ and not $\mathrm{Ra}$ is calculated from the steady state equation at tracer steady state. To calculate Ra from Rd, Eq. 9 or 13 must be used. In this context it should be realized that the rate of change in glucose concentrations was relatively small $\left(0.52 \mathrm{mmol} \cdot \mathrm{l}^{-1} \cdot \mathrm{h}^{-1}\right)$, and therefore, if glucose concentration is measured only over a short period of $30 \mathrm{~min}$, as in many previous studies, this trend may easily be missed. However, using the trends calculated over the $6 \mathrm{~h}$ study period the difference between $\mathrm{Rd}$ and $\mathrm{Ra}$ was on average $12.4 \pm 1.9 \mathrm{mg} \cdot\left(\mathrm{m}^{2}\right)^{-1} \cdot \mathrm{min}^{-1}$ using the whole pool, or $8.1 \pm 1.2 \mathrm{mg} \cdot\left(\mathrm{m}^{2}\right)^{-1} \cdot \mathrm{min}^{-1}$ if only a fraction $(0.65)$ of the pool is used, as in Steele's equations. Furthermore, these differences were correlated to fasting plasma glucose concentrations (Fig.2). Therefore, by assuming that Ra was calculated from the steady state equation also these studies may have overestimated glucose production in proportion to fasting plasma glucose concentrations.
The fact that most previous studies may have overestimated glucose production in proportion to fasting hyperglycaemia is important because a close correlation between fasting plasma glucose concentrations and hepatic glucose production has been used as an argument for the importance of the liver in the pathogenesis of hyperglycaemia in patients with Type 2 diabetes [1]. Also in studies of different therapies this error is important. If the therapy under study reduces the plasma glucose concentration, the mere reduction of fasting hyperglycaemia will also reduce the overestimation of glucose production. Consequently an effect of that therapy on glucose production may erroneously be assumed.

In summary tracer equilibrium in Type 2 diabetic patients is most quickly achieved when the ratio of priming dose and constant tracer infusion rate is adjusted to fasting hyperglycaemia. Using a fixed ratio more than $6 \mathrm{~h}$ may be required. The basal fasting state in Type 2 diabetes is not a steady state situation since plasma glucose concentration is decreasing at a rate of about $0.5 \mathrm{mmol} \cdot \mathrm{l}^{-1} \cdot \mathrm{h}^{-1}$. Therefore, by estimating glucose production $2 \mathrm{~h}$ after fixed priming or by assuming steady state conditions, most previous studies may have overestimated basal glucose production in Type 2 diabetes in proportion to fasting hyperglycaemia.

Acknowledgements. The technical assistance of Ms. S. Nielsen, Ms. B. Mottlau, Ms. A. Thorburn, Ms. B. Topsøe Jensen, Mr. A. Vaag and Mr. M.Lauritzen is gratefully acknowledged. The study was supported in part by grants from the NOVO Research Foundation, the Danish Diabetes Association and Danish Medical Research Council.

\section{References}

1. Olefsky JM (1985) Pathogenesis of insulin resistance and hyperglycemia in non-insulin-dependent diabetes mellitus. Am J Med 79 [Suppl 3B]: 1-7

2. Scarlett JA, Gray RS, Griffin J, Olefsky JM, Kolterman OG (1982) Insulin treatment reverses the insulin resistance of type II diabetes mellitus. Diabetes Care 5: 353-363

3. Revers RR, Fink R, Griffin J, Olefsky JM, Kolterman OG (1984) Influence of hyperglycemia on insulin's in vivo effects in type II diabetes. J Clin Invest 73: 664-672

4. Garvey WT, Olefsky JM, Griffin J, Hamman RF, Kolterman OG (1985) The effect of insulin treatment on insulin secretion and insulin action in type II diabetes mellitus. Diabetes 34: 222-234

5. Henry RR, Scheaffer L, Olefsky JM (1985) Glycemic effects of intensive caloric restriction and isocaloric refeeding in non-insulin dependent diabetes mellitus. J Clin Endocrinol Metab 61: 917-925

6. Kolterman OG, Gray RS, Shapiro G, Scarlett JA, Griffin J, Olefsky JM (1984) The acute and chronic effects of sulfonylurea therapy in type II diabetic subjects. Diabetes 33: 346-354

7. Kolterman OG, Gray RS, Griffin J, Burstein P, Insel J, Scarlett JA, Olefsky JM (1981) Receptor and postreceptor defects contribute to the insulin resistance in non-insulin-dependent diabetes mellitus. J Clin Invest 68: 957-969

8. Henry RR, Wallace P, Olefsky JM (1986) Effects of weight loss on mechanisms of hyperglycemia in obese non-insulin-dependent diabetes mellitus. Diabetes 35: 990-998

9. Osei K, Falko JM, O’Dorisio TM, Fields PG, Bossetti B (1986) Gastric inhibitory polypeptide responses and glucose turnover rates after natural meals in type II diabetic patients. J Clin Endocrinol Metab 62: 325-330

10. Bogardus C, Lillioja S, Howard BV, Reaven G, Mott D (1984) Relationships between insulin secretion, insulin action, and fast- 
ing plasma glucose concentration in non-diabetic and non-insulin-dependent diabetic subjects. J Clin Invest 74: 1238-1246

11. Firth RG, Bell PM, Marsh HM, Hansen I, Rizza RA (1986) Postprandial hyperglycemia in patients with non-insulin-dependent diabetes mellitus. Role of hepatic and extrahepatic tissues. J Clin Invest 77: 1525-1532

12. Golay A, Swislocki ALM, Chen Y-DI, Reaven GM (1987) Relationships between plasma-free fatty acid concentration, endogenous glucose production, and fasting hyperglycemia in normal and non-insulin-dependent diabetic individuals. Metabolism 36: 692-696

13. Baron AD, Schaeffer L, Shragg P, Kolterman OG (1987) Role of hyperglucagonemia in maintenance of increased rates of hepatic glucose output in type II diabetics. Diabetes 36: 274-283

14. Osei K, Holland GC (1987) Clinical correlates of basal hepatic glucose output and metabolic clearance rate of glucose using glucose-C-peptide-body mass indexes in ambulatory type 2 diabetic patients. Diab Res 5: 181-187

15. Firth R, Bell P, Marsh M, Rizza RA (1987) Effects of tolazamide and exogenous insulin on pattern of postprandial carbohydrate metabolism in patients with non-insulin-dependent diabetes mellitus. Diabetes 36: 1130-1138

16. Firth RG, Bell PM, Rizza RA (1986) Effects of tolazamide and exogenous insulin on insulin action in patients with non-insulindependent diabetes mellitus. $N$ Engl J Med 314: 1280-1286

17. Nankervis A, Proietto J, Aitken P, Harewood M, Alford F (1982) Differential effects of insulin therapy on hepatic and peripheral insulin sensitivity in Type 2 (non-insulin-dependent) diabetes. Diabetologia 23: $320-325$

18. Campbell PJ, Mandarino LJ, Gerich JE (1988) Quantification of the relative impairment in actions of insulin on hepatic glucose production and peripheral glucose uptake in non-insulin-dependent diabetes mellitus. Metabolism 37: 15-21

19. DeFronzo RA, Ferrannini E, Simonson DC (1989) Fasting hyperglycemia in non-insulin-dependent diabetes mellitus. Contribution of excessive hepatic glucose production and impaired tissue glucose uptake. Metabolism 38: 387-395

20. DeFronzo RA, Gunnarson R, Björkman O, Olsson M, Wahren J (1985) Effects of insulin on peripheral and splanchnic glucose metabolism in non-insulin-dependent (type II) diabetes mellitus. J Clin Invest 76: 149-155

21. DeFronzo RA, Simonson D, Ferrannini E (1982) Hepatic and peripheral insulin resistance: a common feature of Type 2 (noninsulin-dependent) and Type 1 (insulin-dependent) diabetes mellitus. Diabetologia 23: 313-319

22. Ferrannini E, Simonson DC, Katz LD, Reichard G, Bevilacqua S, Barrett EJ, Olsson M, DeFronzo RA (1988) The disposal of an oral glucose load in patients with non-insulin-dependent diabetes. Metabolism 37: 79-85

23. Simonson DC, Ferrannini E, Bevilacqua S, Smith D, Barrett E, Carlson R, DeFronzo RA (1984) Mechanism of improvement in glucose metabolism after chronic glyburide therapy. Diabetes 33: $838-845$

24. Hother-Nielsen O, Schmitz O, Andersen PH, Pedersen O, BeckNielsen $H$ (1988) In vivo action of glibenclamide in obese subjects with mild type 2 (non-insulin dependent) diabetes. Diabetes Res 8: 63-70

25. Hother-Nielsen O, Schmitz O, Bak J, Beck-Nielsen H (1987) Enhanced hepatic insulin sensitivity, but peripheral insulin resistance in patients with Type 1 (insulin-dependent) diabetes. Diabetologia 30: 834-840

26. McGuire EAH, Helderman JH, Tobin JD, Andres R, Berman M (1976) Effects of arterial versus venous sampling on analysis of glucose kinetics in man. J Appl Physiol 41: 565-573

27. Frayn KN (1983) Calculation of substrate oxidation rates in vivo from gaseous exchange. J Appl Physiol 55: 628-634
28. Ferrannini $E$ (1988) The theoretical basis of indirect calorimetry: a review. Metabolism 37: 287-301

29. Andersen I, Hannibal S (1983) Analytical and economical optimization of a glucose method with immobilized enzymes. J Automatic Chem 5: 188-192

30. Heding LG (1966) A simplified insulin radioimmunoassay method. In: Donato L (ed) Labelled proteins in tracer studies. European atomic energy community, Brussels, pp 345-350

31. Heding LG (1975) Radioimmunological determination of human C-peptide in serum. Diabetologia 11: 541-548

32. Ørskov H, Thomsen HG, Yde H (1968) Wick chromatography for rapid and reliable immunoassay of insulin, glucagon and growth hormone. Nature 219: 193-195

33. Ferrannini E, Del Prato S, DeFronzo RA (1986) Glucose kinetics. Tracer methods. In: Clarke WL, Larner J, Pohl SL (eds) Methods in diabetes research, Vol 2. John Wiley, New York Chichester Brisbane Toronto Singapore, pp 107-141

34. Katz J (1979) Use of isotopes for the study of glucose metabolism in vivo. In: Kornberg NL (ed) Techniques in metabolic research, B207. Elsevier, Amsterdam, pp1-22

35. Shipley RA, Clark RE (1972) Tracer methods for in vivo kinetics. Theory and applications. Academic Press, New York, pp 145-162

36. Steele R (1959) Influence of glucose loading and of injected insulin on hepatic glucose output. Ann NY Acad Sci 82: 420-430

37. DeBodo R, Steele R, Altszuler N, Dunn A, Bishop J (1963) On the hormonal regulation of carbohydrate metabolism: studies with $\mathrm{C}^{14}$-glucose. Recent Progr Horm Res 19: 445-488

38. Shipley RA, Clark RE (1972) Tracer methods for in vivo kinetics. Theory and applications. Academic Press, New York, pp 163-175

39. Wolfe RR (1984) Tracers in metabolic research: radioisotope and stable isotope/mass spectrometry methods. Laboratory and research methods in biology and medicine, Vol 9. Alan R Liss, New York

40. Cowan JS, Hetenyi S (1971) Glucoregulatory responses in normal and diabetic dogs recorded by a new tracer method. Metabolism 20: 360-372

41. Finegood DT, Bergman RN (1983) Optimal segments: a method for smoothing tracer data to calculate metabolic fluxes. Am J Physiol 244: E472-E479

42. Glauber H, Wallace P, Brechtel G (1987) Effects of fasting on plasma glucose and prolonged tracer measurement of hepatic glucose output in NIDDM. Diabetes 36: 1187-1194

43. Hother-Nielsen O, Schmitz O, Andersen PH, Beck-Nielsen $\mathrm{H}$, Pedersen O (1989) Metformin improves peripheral but not hepatic insulin action in obese patients with type II diabetes. Acta Endocrinol (Copenh) 120: 257-265

44. Chen Y-DI, Jeng C-Y, Hollenbeck CB, Wu M-S, Reaven GM (1988) Relationship between plasma glucose and insulin concentration, glucose production, and glucose disposal in normal subjects and patients with non-insulin-dependent diabetes. J Clin Invest $82: 21-25$

45. Chen Y-DI, Swislocki ALM, Jeng C-Y, Juang J-H, Reaven GM (1988) Effect of time on measurement of hepatic glucose production. J Clin Endocrinol Metab 67: 1084-1088

46. Radziuk J, Lickley HLA (1985) The metabolic clearance of glucose: measurement and meaning. Diabetologia 28: 315-322

Received: 3 March 1989

and in final revised form: 8 March 1990

Dr. O. Hother-Nielsen

Second University Clinic of Internal Medicine

Aarhus Kommunehospital

DK-8000 Aarhus C

Denmark 